\title{
Identifikasi Kandungan Senyawa Kimia Cuka Kayu dari Sekam Padi
}

\author{
Dian Laila Nugrahaini ${ }^{1}$, Endang Kusdiyantini ${ }^{2}$, Udi Tarwotjo ${ }^{2}$, A. Heru Prianto ${ }^{3}$ \\ ${ }^{1}$ Program Studi Biologi Departemen Biologi FSM Undip \\ ${ }^{2}$ Laboratorium Bioteknologi dan Ekologi \& Biosistematik Departemen Biologi FSM Undip \\ ${ }^{3}$ Laboratorium PSHB UPT Biomaterial LIPI \\ Departemen Biologi Fakultas Sains dan Matematika Universitas Diponegoro \\ Semarang 50275 Tlp. (024) 7474754; Fax. (024) 76480690. \\ Email:dianlailanugrahaini@gmail.com
}

\begin{abstract}
Wood vinegar rice husk contains a chemical compound that can be used as a biopesticides. Wood vinegar contained compounds which estimated potential as repellent, antifeedant, antimicrobials, antioxidants, disinfectants and as preservatives. The content of chemical compounds in the wood vinegar must be identified. Identification were done by calculating the concentration of acid, phenol and an infrared spectrophotometer. Production of wood vinegar made by the pyrolysis process used pirolisator. Most of the wood vinegar obtained is evaporated using a rotary evaporator and partly extracted using the method of separating funnel. Compound of acid and phenol in wood vinegar evaporation were higher than the extraction of wood vinegar. These results were confirmed by an infrared spectrophotometer spectrum showed the functional groups of acid and phenolic compounds.
\end{abstract}

Keywords: wood vinegar rice husk, acid, phenol, pyrolysis, infrared spetrofotometer

\begin{abstract}
Abstrak
Cuka kayu sekam padi memiliki kandungan senyawa kimia yang dapat digunakan sebagai bioinsektisida alami.Cuka kayu mengandung senyawa-senyawa yang diperkirakan berpotensi sebagai repellent, antifeedant, antimikroba, antioksidan, desinfektan dan sebagai zat pengawet.Kandungan senyawa kimia pada cuka kayu perlu dilakukan identifikasi. Identifikasi dilakukan dengan menghitung kadar asam, kadar fenol dan spektrofotometer inframerah. Produksi cuka kayu dilakukan dengan proses pirolisis menggunakan pirolisator.Sebagian cuka kayu yang diperoleh dievaporasi menggunakan rotary evaporator dan sebagian lagi diekstraksi menggunakan metode corong pisah. Kadar asam dan kadar fenol pada cuka kayu evaporasi lebih tinggi daripada cuka kayu ekstraksi. Hasil ini diperkuat dengan hasil spektrum spektrofotometer inframerah yang menunjukkan gugus fungsi dari senyawa fenol dan asam lebih banyak pada cuka kayu evaporasi.
\end{abstract}

Kata Kunci : Cuka kayu sekam padi, asam, fenol, pirolisis, spetrofotometer inframerah

\section{PENDAHULUAN}

Indonesia merupakan Negara kaya akan berbagai sumber daya alam yang jenisnya sangat bervariasi dan memiliki banyak potensi yang belum banyak diketahui. Banyak tumbuhan yang belum diteliti secara ilmiah, namun dipercaya memiliki kemampuan yang dapat membantu kehidupan manusia.Indonesia merupakan Negara yang sebagian besar mata pencaharian penduduknya adalah petani.Sektor pertanian Indonesia sangat berkembang dan banyak menghasilkan produk pertanian yang melimpah. Produksi sektor pertanian semakin menurun seiring berjalannya waktu, salah satunya disebabkan oleh berbagai serangan hama maupun penyakit terhadap tanaman produksi para petani. 
Upaya petani yang dilakukan untuk menanggulangi masalah ini yaitu dengan menggunakan insektisida kimiawi.Dampak negatif penggunaan insektisida kimiawi yang berlebihan dapat mempengaruhi lingkungan maupun manusia.Penggunaan yang dilakukan secara terusmenerus dapat mencemari lingkungan dan merusak keseimbangan ekosistem alam. Selain itu, penyebab hama yang resisten dari waktu ke waktu juga disebabkan karena penggunaan insektisida yang sangat berlebihan sehingga tidak dapat diuraikan oleh lingkungan sekitar. Sedikitnya pemanfaatan limbah yang ada di lingkungan sekitar mendorong penggunaannya sebagai bahan baku untuk pembuatan bioinsektisida yang ramah lingkungan. Salah satu limbah yang dianggap tidak bermanfaat dan tidak banyak pemanfaatan yang dilakukan yaitu sekam padi.Sekam padi memiliki berbagai komponen kimia yang dapat berperan sebagai bioinsektisida.Sekam padi merupakan limbah yang pemanfaatannya masih sedikit. Sekam padi dapat dimanfaatkan sebagai bahan baku pembuatan cuka kayu dengan proses pirolisis yang dapat digunakan sebagai insektisida organik (Putri dkk., 2015).

Menurut Haji et al., (2007), analisis kandungan kimia cuka kayu dari bahan sampah organik dengan teknik GC-MS yaitu menunjukkan terdapat 61 senyawa penyusun cuka kayu. Senyawa yang teridentikasi tersebut antar lain 17 senyawa $(27,9 \%)$ golongan keton, 14 senyawa (23\%) yang merupakan golongan senyawa fenolik, 8 senyawa (13\%) golongan asam karboksilat, 7 senyawa (11,5\%) alkohol, 4 senyawa (6,6\%) golongan ester, 3 senyawa $(4,9 \%)$ kelompok aldehid dan senyawa lain1 senyawa (1,6\%). Menurut Nugroho \& Imas (2013), cuka kayu hasil pirolisis dari tempurung kelapa mengandung berbagai senyawa kimia diantaranya yaitu fenol, aldehid, keton, asam organik, alkohol dan ester. Senyawa fenol, asam dan alkohol merupakan senyawa penting yang dapat berpotensi sebagai bioinsektisida alami yang dapat menangulangi gangguan serangan hama maupun pathogen.Identifikasi kandungan senyawa kimia cuka kayu sangat penting untuk mengetahui komponen kimia di dalamnya. Identifikasi dilakukan dengan menghitung kadar asam dan fenol. Hasil ini diperkuat dengan analisis menggunakan spektrofotometer inframerah. Penelitian ini dilakukan identifikasi cuka kayu yang diperoleh dari proses pirolisis.

\section{BAHAN DAN METODE Alat dan Bahan}

Bahan utama adalah sekam padi yang diperoleh dari daerah Sampora kelurahan Cibinong, Bogor.Bahan kimia yang digunakan dalam penelitian adalah larutan madu $10 \%$, $\mathrm{Na}_{2} \mathrm{CO}_{3} 15 \%$, reagen Folin-Ciocalteau, fenol, indikator $\mathrm{PP}, \mathrm{NaOH} 0,1 \mathrm{~N}$, asam oksalat $0,1 \mathrm{~N}$ dan aquades.

Alat yang digunakan adalah pirolisator, thermodetectorOMEGA, pH meter digital Cybers can $\mathrm{pH} 110$, timbangan analitik Boeco, oven, rotary evaporatorIKA HB 10, spektrofotometer UV-VIS, spektrofotometer inframerah / FT-IR dan peralatan gelas kimia.

\section{Prosedur Penelitian \\ Persiapan Bahan Baku}

Penyiapan bahan baku dilakukan dengan pengambilan bahan baku, penimbangan bahan baku dan pengukuran kadar air bahan baku.

\section{Produksi Cuka Kayu}

Proses pirolisis dilakukan dengan menggunakan peralatan pirolisis yang disebut pirolisator yang bertujuan untuk menghasilkan cuka kayu dari bahan baku yang digunakan yaitu sekam padi. Sekam padi dimasukkan ke dalam tabung pirolisator, kemudian di tutup rapat (diusahakan tidak ada oksigen).Alat pirolisator dipanaskan dengan tungku yang dihubungkan dengan regulator tabung gas lalu suhu dalam tabung pirolisator diukur menggunakan thermodetectordan dicatat.Cuka kayu yang dihasilkan ditampung dalam wadah. Setelah pembakaran berlangsung selama 5 jam tungku dimatikan dan pirolisator dibiarkan dingin secara alami (Haji et al., 2012).

\section{Evaporasi Cuka Kayu}

Cuka kayu hasil pirolisis dievaporasi menggunakan rotary evaporator. Proses evaporasi dilakukan dengan 3 tahap perlakuan suhu yang berbeda yaitu $60^{\circ} \mathrm{C}, 70^{\circ} \mathrm{C}$ dan $60^{\circ} \mathrm{C}$ dengan tekanan 150 mbar dan kecepatan $101 \mathrm{rpm}$. Evaporasi diberhentikan setelah tidak keluar air 
lagi, sehingga diperoleh cuka kayu yang lebih pekat daripada cuka kayu sebelum dievaporasi. Tujuan dari proses evaporasi adalah untuk meminimalkan kadar air yang terkandung di dalam nya setelah proses pirolisis.

\section{Ekstraksi Cuka Kayu}

Proses ekstraksi dilakukan menggunakan metode corong pisah. Cuka kayu murni atau hasil dari pirolisis diekstraksi dengan pelarut campuran antara diklorometan dan air (1:1). Residu dipisahkan dan diekstrak kembali dengan pelarut diklorometan. Proses ekstraksi dihentikan setelah hasil ekstraksi berwarna bening, sehingga diperoleh ekstrak yang berwarna bening dari cuka kayu sebelumnya. Tujuan dari proses ekstraksi adalah untuk meminimalkan senyawa-senyawa yang terdapat dalam cuka kayu sehingga diharapkan hanya senyawa tertentu khususnya yaitu senyawa fenol.

\section{Karakterisasi Cuka Kayu}

Rendemen (Sawitri, 2014)

Jerigen yang bersih ditimbang, lalu diisi cuka kayu hasil pirolisis.Kemudian jerigen yang berisi cuka kayu ditimbang lagi dengan teliti. Selanjutnya ditentukan rendemennya dengan formula berikut:

Rendemen $(\% \mathrm{v} / \mathrm{b})=\frac{\text { Vohume ouka kayu }(E)}{\text { bobot bahan bakw }(E g)} \times 100$ $\%$

\section{Analisis pH (LTP, 1974)}

Nilai $\mathrm{pH}$ cuka kayu yang dihasilkan diukur dengan menggunakan $\mathrm{pH}$ meter digital dengan cara mencelupkan elektroda ke dalam aquades terlebih dahulu dan keringkan dengan tisu. Selanjutnya elektroda dimasukkan ke dalam sampel cuka kayu.

\section{Analisis Kadar Asam (AOAC, 1990)}

Sampel cuka kayu disiapkan.Masing-masing sampel diambil sebanyak $1 \mathrm{~mL}$ ditimbang dengan teliti dan ditambahkan $100 \mathrm{~mL}$ aquades kemudian dihomogenkan. Larutan sampel ditambahkan 3 tetes indikator PP lalu dititrasi dengan larutan $\mathrm{NaOH}$ 0,1 N. Proses titrasi diberhentikan setelah terjadi perubahan warna.

\section{Analisis Kadar Fenol (Senter et al., 1989)}

Sampel cuka kayu diambil sebanyak $1 \mathrm{~mL}$ ditambahkan aquades hingga $500 \mathrm{~mL}$. Sebanyak 1
$\mathrm{mL}$ yang telah diencerkan masukkan ke dalam tabung reaksi kemudian ditambahkan $5 \mathrm{~mL}$ larutan Natrium Karbonat 15\% dan dibiarkan pada suhu kamar selama 10 menit. Sampel ditambahakan 0,5 $\mathrm{mL}$ reagen Folin-Ciocalteau lalu dikocok dan diinkubasi pada suhu kamar selama 30 menit. Absorbansi diukur dengan spektrofotometer UVVIS terhadap larutan blanko yaitu aquades pada panjang gelombang $750 \mathrm{~nm}$.Konsentrasi fenolat larutan sampel dihitung berdasarkan kurva standar yang diperoleh dari larutan fenol murni.

\section{Identifikasi Senyawa dengan Spektrofotometer Inframerah}

Sampel cuka kayu yang akan dianalisis diletakkan pada sampel holder dan ditempatkan pada lintasan sinar alat spektrofotometer inframerah (FTIR).sebanyak satu tetes. Senyawa yang terdeteksi akan muncul sebagai puncak puncak yang membentuk suatu spektrum.

\section{HASIL DAN PEMBAHASAN}

Hasil produksi cuka kayu dengan cara pirolisis disajikan pada Tabel 1.

Tabel 1.Produksi Cuka Kayu dari Sekam Padi

\begin{tabular}{ccccc}
$\begin{array}{c}\text { Kadar } \\
\text { air (\%) }\end{array}$ & $\begin{array}{c}\text { Berat } \\
\text { Sekam } \\
\text { Padi } \\
(\mathrm{kg})\end{array}$ & $\begin{array}{c}\text { Volume } \\
\text { cuka } \\
\text { kayu }(\mathrm{L})\end{array}$ & $\begin{array}{c}\text { Suhu } \\
\text { Rata-rata } \\
\text { Pirolisis } \\
\left({ }^{\circ} \mathrm{C}\right)\end{array}$ & $\begin{array}{c}\text { Rendemen } \\
(\%)\end{array}$ \\
\hline 9,06 & 191,20 & 30,88 & 373,00 & 16,15 \\
\hline
\end{tabular}

Rata-rata kadar air sekam padi yang diperoleh dari hasil perhitungan yaitu 9,06 \%, hal ini sesuai dengan Jamilatun \& Setyawan (2014), bahwa kadar air sekam padi yang baik untuk proses pirolisis yaitu memiliki kadar air maksimum 10\% dimana sekam padi memenuhi syarat yang ditetapkan untuk proses pirolisis. Menurut Ariyani dkk, (2015), kadar air bahan baku pada proses pirolisis akan berpengaruh pada lama waktu dan energi yang terpakai untuk menguapkan kadar air tersebut sehingga proses yang terjadi lebih singkat serta kadar air memiliki massa yang lebih berat daripada senyawa yang terkandung dalam sekam padi yang berpengaruh terhadap pengurangan massa sekam padi. 
Hasil total rendemen cuka kayu dapat dilihat pada Tabel 1. Total rendemen yang didapatkan dari penelitian ini menggunakan bahan baku sekam padi yaitu 16,15\%. Rendemen yang dihasilkan pada penelitian ini lebih rendah dibandingkan hasil dari hasil yang diperoleh Huang et al., (2016), pada pirolisis yang dilakukan menghasilkan produk sekitar $30,40 \%$ pada suhu $500^{\circ} \mathrm{C}$. Hal ini dapat dipengaruhi oleh sistem pirolisis yang dipakai maupun proses kondensasi yang berbeda.Lamanya proses pirolisis yang berlangsung dan suhu yang terlalu tinggi dapat berpengaruh terhadap rendemen yang diperoleh. Hal ini sesuai dengan Haji et al., (2007), bahwa suhu yang terlalu tinggi dan waktu yang terlalu lama pada saat pirolisis dapat mempengaruhi produksi jumlah cuka kayu yang dihasilkan karena suhu dalam kondensor juga akan semakin meningkat sehingga asap tidak terkondensasi sempurna.

\section{pH}

Rata-rata yang diperoleh dari pengukuran derajat keasaman $(\mathrm{pH})$ cuka kayu sekam padi berkisar antara 3,83-4,04.Cuka kayu murni hasil pirolisis mempunyai nilai $\mathrm{pH} 3,86$, cuka kayu hasil evaporasi mempunyai nilai $\mathrm{pH}$ 4,04; sedangkan cuka kayu hasil ekstraksi mempunyai nilai pH 3,83. Menurut Komarayati dkk., (2011), pH cuka kayu berkisar antara 3,20 - 6,80; maka pH cuka kayu dari sekam padi inimenunjukkan bahwa semua sampel bersifat asam.

\section{Kadar Asam}

Ratat-rata kadar asam cuka kayu sekam padi yang diperoleh yaitu berkisar antara 1,5614,415\%. Cuka kayu yang memiliki harga kadar asam tertinggi pada cuka kayu hasil evaporasi yaitu sebesar $4,415 \%$. Sedangkan pada cuka kayu hasil ekstraksi memiliki harga kadar asam yang paling rendah yaitu 1,561\%. Perbedaan kadar asam cuka kayu berpengaruh terhadap tinggi rendahnya kadar fenol yang dihasilkan. Kadar fenol cuka kayu hasil evaporasi yang dihasilkan lebih tinggi daripada sampel yang lain, sehingga kadar asam cuka kayu hasil evaporasi yang dihasilkan pun lebih tinggi dari sampel yang lain. Hal ini sesuai dengan Pamori dkk.,(2015), bahwa jumlah total asam tertitrasibekaitan dengan tinggi rendahnya jumlah senyawa fenolyang terkandung dalam cuka kayu, dimana kadar fenol cuka kayu yang semakin tinggi, maka total asam tertitrasi yang dihasilkan akan semakin tinggi, begitu juga sebaliknya apabila kadar fenol cuka kayu semakin rendah, maka totalasam tertitrasi akan semakin rendah.

\section{Kadar Fenol}

Rata-rata kadar fenol cuka kayu sekam padi yang diperoleh yaitu berkisar antara 0,18 - 0,7\%. Kadar fenol tertinggi pada sampel cuka kayu hasil evaporasi yaitu sebesar $0,7 \%$. Kadar fenol pada penelitian ini lebih rendah dibandingkan pada penelitian Zhai et al., (2015), kadar fenol yang dihasilkan berkisar antara 1,297-4,652\% pada suhu pirolisis yang berbeda. Semakin tinggi suhu dan semakin lama waktu pirolisis maka kadar fenol yang dihasilkan semakin tinggi. Perbedaan kadar fenol pada komponen kimia cuka kayu tergantung pada bahan baku yang digunakan, dimana semakin tinggi kandungan lignin pada bahan baku maka kandungan fenol pada cuka kayu akan semakin besar.

Penentuan kadar fenol dilakukan dengan prinsip Folin-Ciocelteau, dimana reagen FolinCiocelteau dapat bereaksi dengan senyawa fenol sehingga membentuk larutan berwarna biru. Prinsip Folin-Ciocelteau ini didasarkan pada reaksi oksidasi dan reduksi. Na2CO3 digunakan sebagai pemberi suasana basa, karena senyawa fenol hanya akan bereaksi dengan reagen Folin-Ciocelteau dalam kondisi basa. Menurut Wachidah (2013), proses reaksi oksidasi terjadi pada reagen FolinCiocelteau yang mengoksidasi senyawa fenol atau garam alkali dan reaksi reduksi terjadi pada gugus fenolik-hidroksi yang mereduksi asam heteropoli (fosfomolibdat-fosfotungstat) yang ada pada reagen Folin-Ciocelteau menjadi senyawa kompleks molibdenum-tungsten. Kondisi basa dibutuhkan dalam reaksi ini agar senyawa fenol mengalami disosiasi proton menjadi ion fenolat, karena ion fenolat akan mempengaruhi warna larutan yang terbentuk. Semakin besar konsentrasi senyawa fenol maka semakin banyak ion fenolat yang terbentuk dan akan mereduksi asam heteropoli menjadi kompleks molibdenumtungsten sehingga warna biru yang dihasilkan akan semakin pekat. 
Identifikasi Senyawa Kimia Cuka Kayu dengan FTIR (Fourier Transform Infrared) / Spektrofotometer Inframerah.

Identifikasi menggunakan spektrofotometer inframerah dilakukan untuk mengetahui senyawasenyawa kimia yang terkandung dalam sampel cuka kayu.Identifikasi ini dilakukan berdasarkan hasil spektrum yang menyerap sinar inframerah pada frekuensi yang berbeda-beda sesuai dengan gugus fungsi masing-masing senyawa.Hasil dari pola spektrum senyawa cuka kayu evaporasi dan cuka kayu ekstraksi dapat dilihat pada Gambar 1.dan Gambar 2.

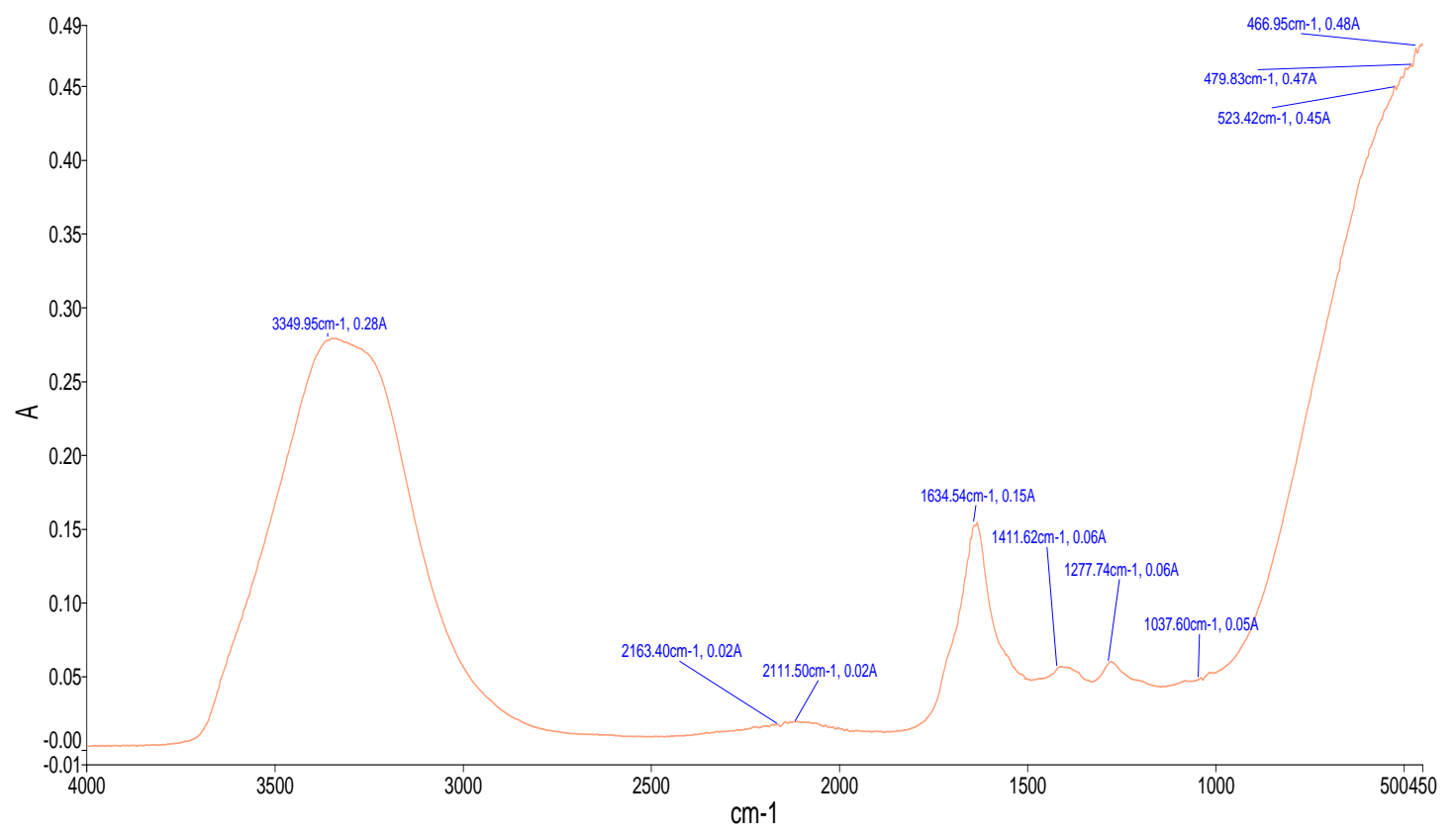

Gambar 1. Spektrum Inframerah Cuka Kayu Evaporasi 


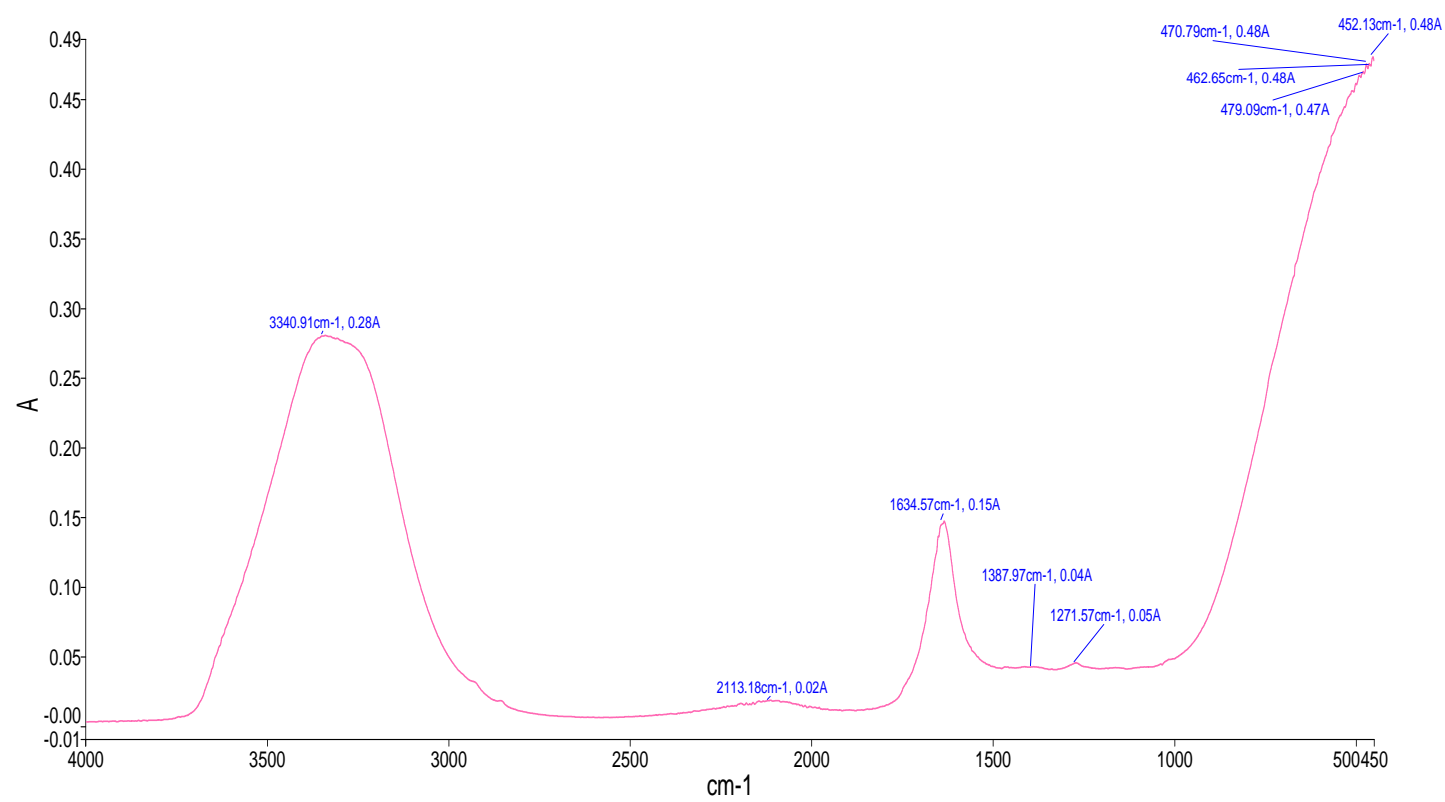

Gambar2. Spektrum Inframerah Cuka Kayu Ekstraksi

Hasil analisis spektrum inframerah cuka kayu evaporasi (Gambar 1) menunjukkan bahwa adanya senyawa asam dan fenol. Berdasarkan analisis spektrumadanya serapan melebar dengan intensitas cukup tinggi pada daerah bilangan gelombang $3349,95 \mathrm{~cm}^{-1}$ yang diduga adalah serapan vibrasi tekuk O-H diduga kelompok fenol. Adanya Serapan tajam dengan intensitas lemah pada daerah bilangan gelombang $1634,54 \mathrm{~cm}^{-1}$ dan diperkuat dengan adanya serapan pada bilangan gelombang 1411,62 $\mathrm{cm}^{-1}$ yang diduga adalah serapan vibrasi uluran $\mathrm{C}=\mathrm{C}$.Serapan uluran $\mathrm{C}$ Oyang tajam dan lemah muncul pada daerah bilangan gelombang $1277,74 \mathrm{~cm}^{-1}$ dan $1037,60 \mathrm{~cm}^{-}$ 1 diduga senyawa kelompok asam. Menurut Sulistyo dkk.,(2013), adanya gugus fungsi $\mathrm{O}-\mathrm{H}$, $\mathrm{C}=\mathrm{C}$ dan $\mathrm{C}-\mathrm{O}$ mengindikasikan positif terdapat senyawa flavonoid yang merupakan kelompok senyawa fenol, serta dikuatkan dengan vibrasi ulur $\mathrm{C}-\mathrm{O}$ yang termasuk dalam golongan senyawaan fenol.

Hasil analisis spektrum inframerah pada sampel cuka kayu ekstraksi (Gambar 2) juga menunjukkan adanya senyawa asam dan fenol seperti pada sampel cuka kayu evaporasi, namun perbedaannya pada banyaknya senyawa yang ada serta pada kondisi serapan yang berbeda.Adanya serapan melebar dengan intensitas yang cukup tinggi pada daerah bilangan gelombang $3340,91 \mathrm{~cm}^{-1}$ yang diduga adalah kelompok senyawa fenol dengan vibrasi tekuk O-H. Pita serapan yang tajam dengan intensitas rendah pada bilangan gelombang $1634,57 \mathrm{~cm}^{-1}$ menunjukkan adanya uluran $\mathrm{C}=\mathrm{C}$, sedangkan serapan uluran melebar dengan intensitas rendah pada bilangan gelombang $1271,57 \mathrm{~cm}^{-1}$ menunjukkan adanya vibrasi ulur C-O. Menurut Sulistyo dkk., (2015), bahwa adanya gugus vibrasi tekuk $\mathrm{O}-\mathrm{H}$ menunjukkan adanya senyawa fenol, uluran $\mathrm{C}=\mathrm{C}$ aromatis dan vibrasi ulur C-O merupakan gugus ester. Menurut Sari dkk., (2015), terdapatnya gugus ester menunjukkan adanya ikatan ester antara gugus hidroksi pada glukosa dengan gugus karboksil dari asam fenolat.

\section{KESIMPULAN}

Cuka kayu memiliki kandungan senyawa kimia antara lain yaitu asam karboksilat, fenol, alkena dan asam

\section{DAFTAR PUSTAKA}

Ariyani, D., Dwi, R. M. dan Dewi, U.Y. A. H. 2015. Studi Kajian Kandungan Senyawa pada Asap Cair dari Sekam Padi.Prosiding 
Seminar Nasional Kimia.Jurusan Kimia FMIPA Universitas Negeri Surabaya. Surabaya.

Association of Official Agricultural Chemist (AOAC). 1995. Official Methods of analysis of AOAC International. Arlington, Virginia, USA.

Bakri.2008. Komponen Kimia dan Fisik Abu Sekam Padi sebagai SCM untuk Pembuatan Komposit Semen.Jurnal Parennial. 5(1): 914.

Dias, M.I., Maria, J. S., Rita, C. A., and Isabel, C.F.R. F. 2015.Exploring plant tissue culture to improve the production of phenolic compounds: A review.Industrial Crops and Products 82(2016) : 9-22.

Fatimah, F., dan Jaka, N. 2005. Identifikasi Hasil Pirolisis Serbuk Kayu Jati Menggunakan Principal Component Analysus.Jurnal Ilmu Dasar 6(1) : 41-47.

Haji, A.G., Zainal, A. M., Bibiana, W. L., Surjono, H. S., dan Gustan, P. 2007. Karakterisasi Asap Cair Hasil Pirolisis Sampah Organik Padat(Characterization Of Liquid Smoke PyrolyzedFrom Solid Organic Waste). Jurnal Teknologi Industri Pertanian 16(3) :111-118.

2012. Identifiasi Senyawa

Bioaktif antifeedant dari asap cair hasil pirolisis sampah organik perkotaan. Jurnal Bumi Lestari 12(1) : 1-8.

Hidayat, T. 2015. Studi Eksperimen Pemilihan Biomassa untuk Memproduksi Gas Asap Cair ( Liquid Smoke Gases ) sebagai Bahan Pengawet. Jurnal SIMETRIS.6(1) : 189-196.

Huang, A-N., C-P Hsu , B-R Houa dan H-P Kuo. 2016. Production and separation of rice husk pyrolysis bio-oils froma fractional distillation column connected fluidized bed reactor. Powder Technology.1-6.

Jamilatun, S. dan Martomo, S. 2014. Pembuatan Arang Aktif dari Tempurung Kelapa dan Aplikasinya untuk Penjernihan Asap Cair.Spektrum Industri.12(1): 1 - 112.

Komarayati,S., Gusmailina dan Gustan, P. 2011. Produksi Cuka Kayu Hasil Modifikasi Tungku Arang Terpadu. Jurnal Penelitian Hasil Hutan.29(3): 234-247.
Lembaga Teknologi Pertanian (LTP). 1974. Metode dan Prosedur Peeriksaan Kimiawi Hasil Perikanan. LTP ; Dirjen Perikanan, Departemen Pertanian. Jakarta.

Ningsih, L.S. 2011. Pembuatan Asap Cair dari Sekam Padi dengan Proses Pirolisa untukMenghasilkanInsektisidaOrganik.Skrip si.UniversitasAndalas. Padang.

Nugraha, G. 2012. Peningkatan Nilai Kalor Biobriket Campuran Kulit Mete dan Sekam Padi melalui Metode Pirolisis.Skripsi. Fakultas Teknik, Jurusan Teknik Mesin, Universitas Diponegoro. Semarang.

Pamori,R., Raswen, E., dan Fajar, R. 2015. Karakteristik Asap Cair dari Proses Pirolisis Limbah Sabut Kelapa Muda.SAGU.14(2) : 43-50.

Prasetyowati, Ayu, P.N., dan Mutia,R. H. 2014. Pembuatan Asap Cair dari Limbah Kulit Singkong (Manihot Esculenta L. Skin) untuk Bahan Pengawet Kayu.Jurnal Teknik Kimia. 1(20) : 64-75.

Prawira, H.,H.A. Oramahi, D. Setyawati dan F. Diba. 2013. Aplikasi Asap Cair dari Kayu Laban (Vitex pubescens Vahl) Untuk Pengawetan Kayu Karet (Application of Liquid Smoke Vitex pubescens Vahl Wood for Preservation Rubber Wood). Jurnal Hutan Lestari. 1(1): 16-22.

Putri, R.E., Mislaini dan Lisa, S. N. 2015. Pengembangan Alat Penghasil Asap Cair dari Sekam Padi untuk Menghasilkan Insektisida Organik.Jurnal Teknologi Pertanian Andalas. 19(2): 29-36 .

Rahmalinda, Amri, dan Zutiniar. 2014. Studi Komparasi Karakteristik Asap Cair Hasil Pirolisis dari Kulit Durian, Pelepah dan Tandan Kosong Sawit dengan Pemurnian Secara Distilasi. Jurnal Online Mahasiswa (Jom) Bidang Teknik Dan Sains.1(1): 19.jom.unri.ac.id/index.php/JOMFTEKNIK/a rticle/viewFile/2429/2366

Senter, S.D., Robertson, J.A., and Meredith, F.I. 1989. Phenolic compound of the mesocarp of cresthaven peaches during storage and ripening. Journal of Food Science.54 : 1259-1268.

Silviyah, S., Chomsin, S.W. dan Masruroh.2014.Penggunaan Metode FT-IR 
(Fourier Transform Infra Red) untuk Mengidentifikasi Gugus Fungsi pada Proses Pembaluran Penderita Mioma.Physics Student Journal.1-28.

Sulistyo,R., Suratmo, dan Rurini, R. 2015. Sintesis Salisilanilida dari Komponen Utama Minyak Gandapura.Kimia Student Journal.1(1): 805 - 811.

Sungkono, H. dan Darminto. 2006. Studi Spektral Inframerah pada Ferit Spinel Nanokristal MFe2O4 $(\mathrm{M}=\mathrm{Ni}$, Mn dan Zn). Jurnal Fisika dan Aplikasinya.2(2): 1-5.

Wachidah, L.N. 2013.Uji Aktivitas Antioksidan serta Penentuan Kandungan Fenolat dan Flavonoid Total dari Buah Parijoto (Medinilla speciosa Blume).Skripsi.Universitas Islam Negeri Syarif Hidayatullah. Jakarta.
Wang, B., Qingyuan, H., Chandrasekar, V., Hongkang C., Hui G., Ni, C., Wei, C., Xingang, L., and Zhongli, P. 2015. Changes in phenolic compounds and their antioxidant capacities injujube (Ziziphus jujuba Miller) during three edible maturity stages.LWT Food Science and Technology 66(2016) : 56-62.

Zhai,M., Xinyu Wang, Yu Zhang, Peng Dong dan Guoli Qi. 2015. Characteristics of rice husk tar pyrolysis by external flue gas. International Journal Of Hydrogen Energy. 40 (2015): 10780 - 10787. 